\title{
IAMJ
}

INTERNATIONAL

AYURVEDIC

MEDICAL JOURNAL

\section{ROLE OF ANUVASAN BASTI IN FRACTURE HEALING: A REVIEW}

\author{
Priyadeep Rai ${ }^{1}$, P. Hemantha Kumar' ${ }^{2}$ B. Swapna ${ }^{3}$ \\ ${ }^{1}$ MS Scholar, ${ }^{2}$ HOD \& Prof, ${ }^{3}$ Associate Prof. \\ PG Department of Shalya Tantra, National Institute of Ayurveda Deemed to be University Jaipur, Rajasthan, \\ India
}

Corresponding Author: priya.draj93@gmail.com

\section{https://doi.org/10.46607/iamj3109042021}

(Published Online: April 2021)

Open Access

(C) International Ayurvedic Medical Journal, India 2021

Article Received:01/04/2021 - Peer Reviewed:13/04/2021 - Accepted for Publication:15/04/2021

Check for updates

\section{ABSTRACT}

Trauma or injury to the bones and joints has been a challenging state of affairs since the times of prehistoric man. Fracture in Ayurveda is termed as Bhagna which is brilliantly explained and tabulated under the heading 'Bhagna Chikitsa' in the classical texts. Acharya Sushruta, the father of Surgery and the pioneer of Sushruta Samhita has described absolute about fracture's etiology, classification and various techniques for its management. Asthi undergoes musculo-skeletal, traumatical injuries resulting in Bhagna i.e. Fracture which implies to breach or break in the continuity of a bone. It can be classified into two main types-Kanda Bhagna and Sandhi-Mukta. Basti is a basic and remarkable therapy in Asthi-related diseases. As Vata Dosha contributes extensively for the occurrence of Asthi-related diseases because of the Asharya-Asharyi Bhava. The present paper reviews the role and mode of action of Anuvasan Basti in the healing of a fracture. The description available in Ayurvedic texts are as much pertinent in modern times as they were in past.

Keywords: Bhagna, Fracture, Anuvasan Basti, Ayurveda

\section{INTRODUCTION}

Trauma or injury to the bones and joints has been a challenging state of affairs since the times of prehis- toric man. With industrialization, agriculture and transportation the odds of getting injured has in- 
creased to such an extent that epidemiologically, trauma is becoming one of the biggest killers and manglers of human beings all over the world. Ancient science is relevant not just for primary healthcare but also specializes in certain areas and one such area is 'Fracture'. It is defined as complete or incomplete separation in the continuity of a bone. With advancement in medical equipments now a days we can do detailed examination of a fractured bone by radiology. But in bygone times, Acharya Sushruta had devised very practical and exceedingly useful, analytical and detailed methods of ascertaining the different types of fractures and various modalities for management and healing. Fracture healing is a complex physiological process that involves the coordinated participation of hematopoietic and immune cells within bone marrow. Basti as one among the Panchkarma signifies its multifaceted actions.

Material and Methods- Information related to Bhagna and Anuvasan Basti (oil enema) was reviewed from

- Classical Ayurvedic texts

- Modern textbooks

- Articles related to Bhagna and Anuvasan Basti

\section{Literary Review}

Concept of Asthi (Bone) -Asthi Dhatu,among the Sapta Dhatu, is the one which is confer with the prime function of Shareera Dharana (bodily support) and administering the nutrition. As per the law of successive production of Dhatu (Ksheerdadhi Dhatuparinama Nyaya), Asthi is produced from its preceding one, that is from Meda. Prithvi Mahabuta is much more present in bone. Meda creates a consolidated mass of Prithvi, Agni, Anil etc its own heat and forms the bones. Vayu creates sponginess of the interior of bones which is filled with Sneha obtained from Meda; this is also called Majja i.e. Marrow. Vayu and Akash and others form the spongy substance as well ${ }^{1}$.Asthi Dhatu and Vata Dosha are interlinked according to the Ayurvedic principle of Ashraya-Ashrayi Bhava. Based on this principle, Asthi Dhatu is the seat of Vata Dosha. Asthi and Vata are inversely proportional to each other regarding Vridhhi (increase) and Kshaya (decrease). Vridhh Vata leads to Kshaya of Asthi ${ }^{2}$.
Bhagna-Review: The literary meaning of Bhagna is a 'break in continuity of the bone'. According to Amarkosh the word Bhagna is derived from "Bhang" Dhatu and "Kta" Pratyaya, which means 'to break'. Bheda, Bhedana, Vibhanga, Bhanjana are all words which can be used as synonyms for 'Bhagna'. Thus, it means as the result of an external force by a hard object the bone must break. Bhagna can be classified into two main types-Kanda Bhagna and SandhiMukta. Kanda-Bhagna is the break in continuity through the bones and Sandhi-Mukta is the break in continuity through the joints. Even modern medical literature defines fractures and dislocations the same way as in the ancient science. The word Bhagna in Ayurrvedic texts refers to both-fractures and dislocations.

The principal cause of Bhagna (Fracture) is violence happening either direct or indirect. Direct violence fracture occurs at the point of impact. And in case of Indirect fracture, a bone away from the point of impact gets fractured due to transmission of force there. Acharya Sushruta tells that the causes for fracture are falling from a height, compression, strike by a rod, extensive pulling of extremities, attack by a wild animal $^{3}$. Vagbhata, in Ashtanga Sangraha has also stated the same opinion concerning the cause of fracture ${ }^{4}$ Besides age, sex, occupation, diseases, etc are the associated factors for occurring fracture. By proper history taking and clinical findings, fracture can be diagnosed easily. He quoted the signs and symptoms same as would be mentioned in any modern surgical textbook. Acharya Sushruta's view in this aspect is much astonishing and is yet admired. He mentioned the signs and symptoms, both in general and specific.

\section{General Features of Kanda Bhagna}

- Svayathubahaulyam (Marked Swelling): Typically, fracture whether it is hairline or comminute, it is to be associated with moderate to severe swelling.

- Sparshaasahishnutvam (Tenderness): It is invariably present altogether varieties of fractures.

- AvapidyamaneShabda (crepitus): is a definite sign of fracture to verify diagnosing. 
- Vividhavedanapradurbhavah (Different types of pain): the broken bone before its reduction and immobilization produces variety of pain. The degree of pain depends on various factors such as nature of trauma, bone fractures, displacement of the fragments and nature of soft injury.

- Sarvasuavasthasunabramalabha (inability to get comfort in any position): fracture provides pain and discomfort to the patient until it is immobilized. The discomfort is specified patient keeps resting the fractured part, in a single posture, does not produce any movement, as this is able to produce to the pain

\section{Management of Bhagna ${ }^{6}$}

Bhagna Sthapana (Reduction): Sushruta has accentuated upon the closed reduction techniques by the use of assorted forces like Aanchhana (traction), Peedana (compression), Sankshepana (reduction or compression), Unmanna (pulling upwards), Vinmanna (pressing downwards). This is the first principle of fracture treatment and is done if required.

Bandhana (Immobilisation): Once the injury has been reduced or corrected it needs to keep in a fixed position such that there is no movement in it, till it unites, or the fractured portion gets sticky. There are two methods which have been stressed upon by Acharya Sushruta for the stabilisation or fixation of fractured part i.e. Kusha and Bandhana (Splintage or external immobilisation) and Kapaat Shayana (fracture bed).

Sukhchestaprasara (Physiotherapy): It is very important to bring back the conventional functions of the affected parts as soon as possible, mainly by gaining the strengths of bones and soft tissues. Under the management of fractures of bones of palm (metacarpals) in Sushruta Samhita has delineated gradually increasing weight bearing. It has been mentioned that the patient should hold Mritpinda (ball of clay) then Lavana (salt) and finally Pashaana (a piece of stone) in his palm to regain the strength.

Concept of Fracture Healing- Bone healing process is to restore the tissue to its original physical and mechanical properties and is influenced by a variety of systemic and local factors; healing occurs in three dis- tinct and overlapping stages. Two basic types of fracture healing are the primary or direct fracture healing and secondary or indirect fracture healing. The primary fracture healing occurs with minimal callus formation. It is direct attempt of bone to re-establish its continuity and thus requires direct contact of cells in the cortex. The majority of fractures heal by secondary or indirect healing. It occurs in four phases hematoma formation, early inflammatory, repair, and late remodelling phase ${ }^{7}$.In the early inflammatory stage, a hematoma develops within the fracture site during the first few hours and days. The primary nutrient and oxygen supply of this early process is provided by exposed cancellous bone and muscle. The use of antiinflammatory or cytotoxic medication during the $1^{\text {st }}$ week may alter inflammatory response and inhibit bone healing. During repair stage, fibroblast begins to lay down a stroma that helps support vascular in growth progress; a collagen matrix is laid down while osteoid is secreted and subsequently mineralized which leads to the formation of a soft callus around repair site. In terms of resistant to movement, this callus is very weak in the $1^{\text {st }} 4-6$ weeks of the healing process and required adequate protection in the form of bracing or internal fixation. Eventually, the callus ossifies forming a bridge of woven bone between the fractured fragments. Fracture healing is completed during remodelling stage in which the healing bone is restored to its original shape, structure, and mechanical stress placed on the bone.

\section{Parenteral Ayurvedic Principle for Fracture Heal- ing}

Bhagna(skeletal injuries) occurring in upper part of the body should be treated with Mastishkya (a type of Sirobasti or to keep a swab of cloth or cotton well soaked with oil over the head) injuries, Karanpura$n a$ (pouring of oil in the ear) and Nasya (nasal medication), and fractures of the extremities should be treated with Anuvasan Basti ${ }^{8}$. Gandha Taila or Trapushadi Taila (Ayurvedic medicated oils) should be used for all these purposes ${ }^{9}$.Elsewhere in Yogratnakara for Bhagna (skeletal injuries) treatment use of Mahavishgarbha Tailam and Mahabala Tailam (Ayurvedic medicated oils) have also been recommended. 
Basti Review - Experiences and experiments in the field of medicines has been remarkably associated with the development and can be considered as fundamental as it can be, these experiments and experiences give an edge and time to establish the credibility of this ancient science, called Ayurveda. One of the fundamental and impressively important elements of Ayurvedic treatment is Panchkarma therapy. It has been established that Panchkarma therapy which includes- Anuvasan, Nasya, Vaman, Virechan and Niruha are crucial to get rid of disease completely. Basti means enema which is medicated. In this process, medicated decoctions and oils are administered through anus in the body with the assistance of instruments specially designed for the process of Basti. One of the fundamental and crucial treatment being Basti is thought to be the "Chikitsardha". In Ayurve$d a$ which implies that it half of the treatment, however myriad effects have been associated with it. It is possessed with multidimensional actions. Basti acts through its Virya ${ }^{10}$, being the active principles of the drug. Basti's active ingredients spread all inside the body to get results that we desire, and it is injected in the body through Pakvashaya i.e. Rectum and Colon. The absorption of Basti Dravyas can be understood by certain references in our classics. This process can be described as similar with the process of water and minerals intake of trees and plants through their roots so Basti does the same to get to each and every part of the body through Pakvashaya. Basti has the prime functioning of colon cleansing. The effects on whole body can be seen of colon cleansing and consequently, it is comparable to the 'Srotoshodhana'. The rationale for colon cleansing is 'Autointoxication', the idea that food enters the intestine and rots ${ }^{11}$. Basti has two types Niruh or Asthapan Basti (decoction enema) and Sneha or Anuvasan Basti (oil enema). In this type, medicated Sneha in the form of oil/Ghee is administered. Anuvasan implies-to stay. The administered medicines do not cause harm after staying for a longer period inside the body.

Vata is prominent Dosha among the three Dosha and it has the ability to move from one place to another. This Vata is responsible for moving Pitta and Kapha from one place to another. Therefore, it is responsible for all diseases either Sakhagata (extremities), Koshtagata (abdominal cavity), Marmagata (vital organs), Urdhwagata (upper body), Adhogata (lower body), Sarvaavayavagata (entire body). So Basti is considered as 'Chikitsardha'. It is specially indicated for Vataj dominant diseases ${ }^{12}$. Acharya Charaka states Basti first acts on Pakvashaya (large intestine) and keeps the Vata in Samavastha (equilibrium). It produces Shamana of Vata. So, all the Vata Vikaras will be diminished just like the tree which is cut by its roots loses the extremities \& Stem, Shakha (branches), Kanda (stem), Pushpa ${ }^{13}$ (flowers)

Probable Mode of Action of Anuvasan Basti-The Anuvasan Basti made in Tail (oil) or Ghrita which have Madhura (sweet) and Snigdha (unctuous) properties helps to control Vata Dosha and due to Sukshma Guna (minute properties) of Saindhva (rock salt) it reaches up to micro channel of the body ${ }^{14}$ and helps to open fresh blood supply to the bone tissue. In this Basti, Dravyas are having Madhur Rasa, Ushana Virya (hot potency) and Madhura Vipaka (pungent post digestive taste) which favours normal functioning of Dhatvagni (metabolic stage) facilitating increased nutrition to the Asthi Dhatu. Ghrita is Vatashamak (pacifier of Vata), Madhura, Shitavirya (cold potency) has the properties of Sanskarasya Anuvartana ${ }^{15}$ (that which inherits the properties of other drugs without altering itself) precipitating bioavailability of other drugs. Thus, it pacifies Vata improves the Dhatu Upachaya (metabolism of the tissue) leading to Samyaka Rasa Raktadi Dhatu Nirmana. Samyaka Rasa Dhatu leads to the formation of Samyakarakta, Mamsa and Uttarottar Dhatu. It strengthens the muscle power of the body and promotes the tissue regeneration. Basti is effective in Asthivaha and Majjavahasrotas. Purishadhara Kala, the colon membrane is considered as Asthidhara Kala, the membrane of the bone tissue. Asthi is important site of Vata Dosha. Hence medications are given rectally affect all the tissues upto bone tissue. Ayurvedic medicated oil's Basti is specially indicated in Bhagna will act on the site of fracture. Gandha taila or Trapushadi taila 
(Ayurvedic medicated oils) was used in Anuvasana Basti which is indicated in Bhagna Chikitsa

\section{DISCUSSION}

According to Ayurveda point of view there is direct relation of fracture with clinical presentation indicate towards dominance of Vata Dosh and Vikruti (vitiation) of Asthi Dhatu (bony tissue). In Bhagna, the blood supply to the bone is decreased due to any type of Margavrodha (occlusion of blood vessels) ultimately leading to delay fracture healing. Margavrodha is also responsible to aggravate Vata Dosha which in turn leads to Dhatu Kshaya which accounts for increased proportion of Vata. So, Basti is first line of treatment of Vata Dosha as well as Margavro$d h a^{16}$.Anuvasantail Basti and there by producing desired effects in the form of:(i) Formation of callus; i.e. 1st step due to the Srotoshodhana effect of Anuvashan Basti - all necessary elements responsible for callus formation reach to the effected site.(ii) Analgesic action- According to Ayurveda Vata dosh responsible for pain. So Basti is first line of treatment of vata Dosha

\section{CONCLUSION}

Basti is an excellent therapy in Asthi-related diseases. Vata Dosha contributes largely for the occurrence of Asthi-related diseases because of the Asharya-Asharyi Bhava. And in modern concept use of antiinflammatory or cytotoxic medication during the $1^{\text {st }}$ week may alter inflammatory response and inhibit bone healing. So Anuvashan Basti can be best option for anti-inflammatory or cytotoxic medication.

\section{REFERENCES}

1. Agnivesha, Charaka Samhita, Ayurveda-Dipika commentary by Chakrapani Dutta, revised ed., Chikitsa Sthana (15:30-33), pg. 348, Chaukhambha Surbharati Prakashan, Varanasi (2011).

2. Ashtangsamgraha of VriddhaVagbhatta with Hindi commentary: vol1, Sutrasthana 20/1 edited by Kaviraj Atridev Gupta, Chaukhambha Sanskrit Prakashan, Varanasi Edition: 2002

3. Sushrut, sushrut Samhita, Nidanasthan $15 / 3$, edited by Ambikadatta shastri, thirteen edition, Chaukhamba
Sanskrit Prakashan, Varanasi, Reprint Edition 2017, pg 377

4. Ashtangsamgraha of Vriddha Vagbhatta with hindicommentary: voll, Sutrasthana $32 / 2$ edited by Kavira jAtridev Gupta, Chaukhambha Sanskrit Prakashan, Varanasi Edition: 2002

5. Sushrut, sushrut Samhita, Nidanasthan 15/9, edited by Ambikadatta shastri, thirteen edition, Chaukhamba Sanskrit Prakashan, Varanasi, Reprint Edition 2017, pg 378

6. Sushruta Samhita of Sushruta with Ayurveda Tatva Sandeepika Hindi commentary by Kaviraj Ambikadatta Shastri, Chikitsa Sthana, Chapter 3/17-21,34-35, Reprint 2nd edition, Chaukhamba Sanskrit Sansthan Varanasi, 2014, p28-

7. Abd Jalil MA, Shuid AN, Muhammad NRole of medicinal plants and natural products on osteoporotic fracture healingEvid Based Complement Alternat Med. 2012;20120:714512.

8. Sushruta Samhita, Ayurvedatatvasandeepika Hindi commentary, by Kaviraj Ambikadatta Shastri Sutra Sthana, Chapter 3/54, Reprint 2nd edition, Chaukhamba Sanskrit Sansthan Varanasi, 2014, p32.

9. Sushruta Samhita, Ayurvedatatvasandeepika Hindi commentary, by Kaviraj Ambikadatta Shastri Sutra Sthana, Chapter 3/54, Reprint 2nd edition, Chaukhamba Sanskrit Sansthan Varanasi, 2014, p32.

10. Sushrut, sushrut Samhita, Chikitsasthan 35/27, edited by Ambikadattashastri, thirteen edition, Chaukhamba Sanskrit Prakashan, Varanasi, Reprint Edition 2017, pg 192

11. Chen TS, Chen PS (1989). "Intestinal autointoxication: a medical leitmotif". J. Clin. Gastroenterol.11 (4): 434-41.

12. Vagbhata, Ashtangahraday, with commentaries, Sarvangasundara of Arunadatta \& Ayurvedarasayana of Hemadri, Edited by Pt. Hari SadasivaSastri Paradakara, Reprint: 2010, Page no.16, Sutrasthana, Chapter No.1, Ayushkamiya Shlok no.26.

13. Agnivesha, Charak Samhita: Charakchandrika, Hindi commentary, Edited by Dr.Bramhanad Tripathi, Chaukhamba Surabharati Prakashan, Varanasi, Edition: 2007, Vol.2, Page no.937, Siddhisthana, Chapter No.1, Kalpanasiddhi, Shlok no. 31

14. Patil, Vasant. Principles \& Practice of Panchakarma (A Comprehensive Book For UG, PG, Researchers \& Practitioners); 4th ed. New Delhi: Chaukhamba Publication; 2014, p.497 
15. Agnivesha, Charak Samhita: Charakchandrika, Hindi commentary, Edited by Dr. Bramhanad Tripathi, Sutrasthana 13/13,p.82 vol:1 Chaukhamba Surabharati Prakashan, Varanasi, Edition: 2007

16. Agnivesha, Charak Samhita Hindi commentary, Edited by Dr. Bramhanad Tripathi, Sutrasthana 28/1516,p.779 vol 1 Chaukhamba Surabharati Prakashan, Varanasi, Edition: 2007

\section{Source of Support: Nil}

\section{Conflict of Interest: None Declared}

How to cite this URL: Priyadeep Raj et al: Role Of Anuvasan Basti In Fracture Healing: A Review. International Ayurvedic Medical Journal \{online\} 2021 \{cited April, 2021\} Available from:

http://www.iamj.in/posts/images/upload/876 881.pdf 